\title{
Effect of Supplementation of Anti-Oxidant Mineral Formulation on Milk SCC and DCC in Bovine Mastitis
}

\author{
A. Muhee ${ }^{1 *}$, H. U. Malik ${ }^{1}$, I. Asharaf ${ }^{1}$, O. S. Shah ${ }^{1}$, A. Jan ${ }^{1}$, Muheet ${ }^{1}$, \\ W. Rather ${ }^{1}$ and Showkeen Muzamil ${ }^{2}$ \\ ${ }^{1}$ Department of Veterinary Medicine ethics and jurisprudence, F.V.Sc \& A.H, \\ SKUAST-K, Srinagar- 192301, Jammu and Kashmir, India \\ ${ }^{2}$ Molecular Biology Lab, Division of Veterinary Biochemistry, Faculty of Veterinary Sciences \& \\ Animal Husbandry, Sheri Kashmir University of Agricultural Science \& Technology-Kashmir \\ (SKUAST-K), Srinagar, J\&K-190006, India \\ *Corresponding author
}

\begin{tabular}{l} 
K e y w o r d s \\
$\begin{array}{l}\text { Supplementation of } \\
\text { anti-oxidant, mineral } \\
\text { formulation }\end{array}$ \\
Article Info \\
$\begin{array}{l}\text { Accepted: } \\
\text { 20 June } 2017 \\
\text { Available Online: } \\
\text { 10 July } 2017\end{array}$ \\
\hline
\end{tabular}

A B S T R A C T
The study was undertaken on clinical cases of bovine mastitis presented to Teaching Veterinary Clinical Complex (TVCC), F.V.Sc \& A.H, SKUAST-K and adjoining areas during the course of study August 2014-May 2016. For therapeutic trials, the clinical cases of mastitis were divided into two groups. In Animals of Group I therapeutic regimen I was used conducted and included 15 clinical cases of mastitis, in Group II animal's therapeutic regimen II was used and included 12 clinical cases of mastitis. The animals of group II were given self-formulated anti-oxidant trace mineral mixture. Group II animals were not given any anti-oxidant trace mineral mixture. Mastitis is characterised by change in the milk SCC and DCC as evidenced by the present study. Further supplementation of antioxidant trace minerals results in early amelioration of milk SCC and DCC as evidenced by normal values in the group supplemented with anti-oxidants as compared to the group not supplemented with anti-oxidants. The requirements of trace minerals like $\mathrm{Cu}, \mathrm{Zn}, \mathrm{Mn}$ and Se are increased in mastitis as evidenced by their decreased levels in clinical mastitis and improved clinical response on their supplementation. Anti-oxidant trace minerals like $\mathrm{Cu}$, $\mathrm{Zn}, \mathrm{Mn}$ and Se significantly aid recovery in bovine mastitis and may play a significant role in prophylaxis of mastitis in lactating animals.

\section{Introduction}

Mastitis is a parenchymal inflammation of the mammary gland, which is caused by microorganisms, usually bacteria that invade the udder, multiply and produce toxins which are harmful to the mammary gland (Sharma et al., 2006). The key response of the cow to infection by pathogens is localized entry of leukocytes (white blood cells) from the blood vessels in the infected tissue into the tissue near the site of infection. The leukocytes that enter the milk in the alveoli are called somatic cells and the concentration of somatic cells in milk is called somatic cell count (SCC). The greater the SCC, the higher the level of inflammation in the tissue. So, SCC in milk is an important indicator of the inflammation status of the udder. The somatic cells present in the milk of a healthy cow belong mainly to 
the macrophages $(66-88 \%)$; in addition there are neutrophils, and epithelial and mononuclear cells (Sandholm, 1995) The proportion of neutrophils is only $1-11 \%$ in a healthy quarter but increases up to $90 \%$ and more in a quarter with intramammary infection(Sandholm, 1995). The proportion of neutrophils as the percentage of the SCC has been proposed as a mastitis indicator (Hamann and Krömker, 1997). It has been suggested that instead of total SCC, differential cell counting should be performed which would provide more information about the health status of a quarter (Östensson et al., 1988) because each somatic cell type has its own specified function in the immune response of the mammary gland; a high SCC can be the result of an increase in PMN cells (Leitner et al., 2000). Therefore in addition to SCC it would be beneficial to know the types of inflammatory cells present in milk. Differential cell count (DCC) in milk or the differential inflammatory cell count is a comparative tool along with SCC to monitor udder health. The present study was therefore undertaken to see the changes in milk SCC and DCC due to mastitis and the effect of supplementation of anti-oxidant trace mineral supplementation on milk SCC and DCC.

\section{Materials and Methods}

\section{Animals}

A total of 39 multiparous cows in the age group of 4-8 years with BCS 3.0 were included for the study. The study was undertaken on clinical cases of bovine mastitis presented to Teaching Veterinary Clinical Complex (TVCC), Faculty of Veterinary Sciences \& Animal Husbandry (F.V.Sc \& A.H), Shere Kashmir University of Agricultural Sciences and Technology of Kashmir (SKUAST-K) and local animal husbandry dispensaries in Ganderbal, Manasbal, Shuhama, Gulab bagh and
Shalimar areas for treatment during the course of study (August, 2014-May, 2016). 27 cases of clinical mastitis were studied and all the animals included were clinical cases and no experimental case was included. 12 apparently healthy lactating animals served as control group. The cases of clinical mastitis were diagnosed on the basis of clinical examination, case history and clinical findings. The severity of the cases was assessed on the basis of CMT score and SCC of milk samples. Cases with CMT score of 2 or 3 with somatic cell counts more than $4 \times 10^{5}$ $/ \mathrm{mL}$ of milk were considered positive for mastitis. For therapeutic trials, the clinical cases of mastitis were divided into two groups. In Group I animals, therapeutic regimen I was used and included 15 clinical cases of mastitis, in Group II animals therapeutic regimen II was used and included 12 clinical cases of mastitis.

For performing therapeutic trials, the mastitic animals as diagnosed by clinical presentation, CMT score and SCC were divided into 2 groups. Group I consisted of 15 cases of clinical mastitis. The animals of this group were given self-formulated anti-oxidant trace mineral mixture at therapeutic doses as recommended by NRC, 2001 whose formulation is given in Annexure 1.All the four ingredients were mixed making a total weight of about 5.005 gms and stored in air tight zip lock polyethene pouches. Total 7 pouches were given to individual animal owners for providing contents of one pouch to the animal once daily for 7 days. The criteria for choosing these trace minerals as supplement was to see the effect of supplementation of these anti-oxidant trace minerals in clinical recovery of mastitic animals and their effect on milk SCC and DCC. Trace elements as copper, iron, zinc, selenium and manganese play important roles in several biochemical processes as they are essential component in the antioxidant 
enzymes as SOD and CAT (Yang and Li, 2015). Group II animals were not given any anti-oxidant trace mineral mixture. Both the groups of animals were given antibiotic enrofloxacin (Inj. Enrocin) at the dose rate of $6.6 \mathrm{mg} / \mathrm{kg}$ per animal twice daily for 5 days. The choice of the antibiotic was based on antibiotic sensitivity test of milk which was performed in each case. Animals which were not found sensitive to enrofloxacin were excluded from the study. The therapeutic trial design for cows with clinical mastitis is provided in Table 1 .

For estimation of trace mineral status for copper, zinc, manganese and selenium, blood samples were collected from healthy lactating animals to obtain baseline values of trace minerals. In clinical cases, blood samples were collected on day 0 and day 10 for estimation of trace mineral status after acid digestion of samples.

\section{Somatic cell count of milk (SCC)}

Somatic cell count was estimated from healthy lactating cows as well as from clinical cases of mastitis on day 0 , day 5 and day 10 of treatment. The somatic cell count of milk samples was done by direct microscopic method. The test milk sample was thoroughly mixed and $10 \mu \mathrm{l}$ of milk was spread on one square $\mathrm{cm}\left(1 \mathrm{~cm}^{2}\right)$ demarcated area of a clean grease free glass slide. The smear of milk was prepared within one hour of its collection to minimise the disintegration of leukocytes and smear was dried at room temperature. The smear was stained with modified Newman's Lampert stain for 1 to 2 minutes and then the smears were washed with tap water and dried. The dried stained smears were examined under oil immersion objective and the number of cells in 20 fields was counted. The fields were selected by moving the slide horizontally from one edge of the film through the centre to the opposite edge and then, repeated in a vertical direction. The average number of cells per field was multiplied by the microscopic factor.

\section{Calibration of the microscope/calculation of microscopic factor}

The diameter of the microscopic field seen through oil immersion objective was measured using a stage micrometer slide ruled in 0.1 and $0.01 \mathrm{~mm}$. The diameter of the field was measured up to two decimal points and the area of the field was calculated using the formula $\Pi r^{2}$.

Area of the smear (in mm2)

Microscopic factor $(\mathrm{MF})=$

Area of the microscopic field

The diameter was 0.16 , then $r=0.08$

100

So, $\mathrm{MF}=\frac{----------------}{}=4976 \approx 5000$

Since, the milk sample taken on the slide was $0.01 \mathrm{ml}$, the total number of cells per $\mathrm{ml}$ of milk was given by the formula,

Cell count per $\mathrm{ml}$ of milk $=$ Average No. of cells per field $\times \mathrm{MF} \times 100$

\section{Milk Differential Cell Count (DCC)}

Milk DCC was estimated from milk of healthy lactating cows as well as from clinical cases of mastitis on day 0 , day 5 and day 10 of treatment. DCC of milk samples was estimated by the method of Dulin et al., (1982). Direct smears were prepared in duplicate. A drop of milk and a drop of trypticase soy broth (TSB) were placed on a clean microscope slide by capillary pipette and spread evenly over the surface with a cover slip. Slides were air dried and stained subsequently with modified Wright's stain. The TSB caused cells to adhere to the 
microscope slide. Identification of different types of cells was done by observing the slide under $100 \mathrm{x}$ magnifications, under oil immersion. On each slide, 200 cells were counted and differentiated into Neutrophils (PMN), lymphocytes and macrophages. The battlement method was used in examining direct smears.

\section{Results and Discussion}

Somatic Cell Count (SCC) was estimated in milk of normal as well as mastitic animals. In mastitic animals the values were estimated on day 0 , day 5 and day 10 of treatment to evaluate the effect of two therapeutic regimens used for treatment of mastitis in Group I and Group II animals. The values are depicted in Tables 2 and 3.

The mean SCC $\left(\times 10^{5} / \mathrm{mL}\right.$ of milk $)$ was $2.83 \pm 0.055$ for normal healthy control group and $9.94 \pm 0.22$ for the mastitic group (Table $2)$. The mean values of SCC $\left(\times 10^{5} / \mathrm{mL}\right.$ of milk) in the mastitic group were statistically significant from the mean values of SCC in the normal control group $(\mathrm{p}<0.05 \%)$.

The mean values for SCC $\left(\times 10^{5} / \mathrm{mL}\right.$ of milk $)$ for group I animals with clinical mastitis receiving therapeutic regimen I were $9.88 \pm 0.31,6.00 \pm 0.36$ and $3.19 \pm 0.10 \times 10^{5} / \mathrm{mL}$ on day 0 , day 5 and day 10 of treatment, respectively (Table 3 ) and the mean values of SCC on day 0, day 5and day 10 in group I animals differed significantly from each other $(\mathrm{p}<0.05)$ The mean values for SCC $\left(\times 10^{5} / \mathrm{mL}\right.$ of milk) for group II animals receiving therapeutic regimen II were $10.03 \pm 0.33$, $7.63 \pm 0.17$ and $4.43 \pm 0.13$ on day 0 , day 5 and day 10 of treatment, respectively and the mean values of SCC on day 0 , day 5 and day 10 in this group of animals also differed significantly $(\mathrm{p}<0.05)$ from each other (Table 3$)$.

Mastitis whether subclinical or clinical leads to an increase in milk cells, particularly the milk leucocytes or somatic cells, decrease in the milk producing mammary epithelial cells, and an altered milk composition (Al Hussein,2015). Our findings of increased SCC during mastitis are also in agreement with Dang et al., (2010) who reported that milk SCC increases significantly in mastitic cows and acts as a protective mechanism to kill the invading pathogens in the mammary gland. Sharma et al., (2011) reported SCC as a useful predictor of intramammary infection (IMI), and therefore, an important component of milk in assessment of aspects of quality, hygiene and mastitis control.

\section{Milk Differential Cell Count (Milk DCC)}

Differential Cell count DCC) was estimated in milk of normal as well as mastitic animals. In mastitic animals the values were estimated on day 0 , day 5 and day 10 of treatment to evaluate the effect of two therapeutic regimens used for treatment of mastitic animals in Group I and Group II. The values are depicted in Tables $2 \& 3$.

\section{Neutrophil (\%)}

The mean neutrophil count (\%) was $17.75 \pm 0.28$ in normal healthy control group and $73.26 \pm 0.78$ in mastitic animals (Table 2). The difference in the mean values of neutrophil (\%) between the healthy control group and themastitic group was statistically significant $(\mathrm{p}<0.05 \%)$. The mean values for neutrophil (\%) in group I animals with clinical mastitis were $72.07 \pm 1.09, \quad 50.2 \pm 1.30$ and $20.67 \pm 0.82$ on day 0 , day 5 and day 10 of treatment with therapeutic regimen I, respectively (Table 3). The mean values of neutrophil (\%) on day 0,5 and 10 of treatment within group I animals differed significantly from each other $(\mathrm{p}<0.05 \%)$. The mean values for neutrophil count (\%) in group II animals with clinical mastitis were $74.75 \pm 0.99$, $50.33 \pm 1.43$ and $27.42 \pm 0.86$ on day 0 , day 5 and day 10 of treatment with therapeutic 
regimen II, respectively. The mean values of neutrophil $(\%)$ on day 0,5 and 10 within this group of animals also differed significantly $(\mathrm{p}<0.05 \%)$ from each other $(3)$.

\section{Lymphocyte (\%)}

The mean lymphocyte count (\%) was $13.67 \pm 0.37$ in normal healthy control group and 6.78 \pm 0.22 in mastitic animals (Table 2). The difference in the mean values of lymphocyte $(\%)$ between the healthy control group the mastitic group was statistically significant $(\mathrm{p}<0.05 \%)$. The mean values for lymphocyte (\%) in group I animals with clinical mastitis were $6.80 \pm 0.31$,
$10.8 \pm 0.54$ and $14.93 \pm 0.41$ on day 0 , day 5 and day 10 of treatment with therapeutic regimen I, respectively (Table 3). The mean values of lymphocyte $(\%)$ on day 0,5 and 10 of treatment within group I animals differed significantly from each other $(\mathrm{p}<0.05 \%)$. The mean values for lymphocyte $(\%)$ in group II animals with clinical mastitis were $6.75 \pm 0.33$, $9.0 \pm 0.30$ and $11.5 \pm 0.34$ on day 0 , day 5 and day 10 of treatment with therapeutic regimen II, respectively. The mean values of lymphocyte count (\%) on day 0,5 and 10 within this group of animals also differed significantly $(\mathrm{p}<0.05 \%)$ from each other (Table $3)$.

\begin{tabular}{|l|l|l|l|l|l|l|}
\hline \multicolumn{7}{|c|}{ Table.1 Therapeutic trial design for cows with clinical mastitis } \\
\hline Group & $\begin{array}{l}\text { No. of } \\
\text { animals } \\
\text { treated }\end{array}$ & Treatment & Dosage & Route & Frequency & $\begin{array}{l}\text { Duration } \\
\text { of } \\
\text { treatment }\end{array}$ \\
\hline $\begin{array}{l}\text { Group I } \\
\text { (Therapeutic } \\
\text { regime I) }\end{array}$ & 15 & $\begin{array}{l}\text { Inj. } \\
\text { Enrofloxacin }\end{array}$ & $\begin{array}{l}6.6 \\
\mathrm{mg} / \mathrm{Kg}\end{array}$ & $\mathrm{I} / \mathrm{M}$ & BID & 5 days \\
$\begin{array}{l}\text { Anti-oxidant } \\
\text { trace mineral } \\
\text { mixture }\end{array}$ & $\begin{array}{l}5.005 \\
\text { gms }\end{array}$ & Oral & OD & 7 days \\
\hline $\begin{array}{l}\text { Group II } \\
\text { Therapeutic } \\
\text { regime II) }\end{array}$ & 12 & $\begin{array}{l}\text { Inj. } \\
\text { Enrofloxacin }\end{array}$ & $\begin{array}{l}6.6 \\
\mathrm{mg} / \mathrm{Kg}\end{array}$ & I/M & BID & 5 days \\
\hline
\end{tabular}

Table.2 Comparison of milk Somatic cell count (SCC) and Differential Cell Count (DCC) between healthy lactating (Control Group) and mastitic animals

\begin{tabular}{|c|c|c|}
\hline Parameters & Control Group & Mastitic Group \\
\hline $\mathrm{SCC}\left(\times 10^{5} / \mathrm{mL}\right)$ & $2.83 \pm .05^{\mathrm{a}}$ & $9.94 \pm 0.22^{\mathrm{b}}$ \\
\hline Neutrophil $(\%)$ & $17.75 \pm .28^{\mathrm{a}}$ & $73.26 \pm 0.78^{\mathrm{b}}$ \\
\hline Lymphocyte $(\%)$ & $13.67 \pm .39^{\mathrm{a}}$ & $6.78 \pm 0.22^{\mathrm{b}}$ \\
\hline Macrophage $(\%)$ & $68.58 \pm .49^{\mathrm{a}}$ & $19.96 \pm 0.77^{\mathrm{b}}$ \\
\hline
\end{tabular}

Values within a row having superscript (a, b) with at least one common alphabet do not differ significantly at 5\% level $(\mathrm{p}<0.05)$ from each other. 
Table.3 Effect of treatment on milk Somatic Cell Count (SCC) and Differential Cell Count (Neutrophil, lymphocyte and macrophage \%) in animals with clinical mastitis

\begin{tabular}{|l|c|c|c|}
\hline \multirow{3}{*}{ Parameters } & $\begin{array}{c}\text { Days of } \\
\text { treatment }\end{array}$ & $\begin{array}{c}\text { Group I } \\
\text { (Antibiotic+Anti- } \\
\text { oxidant trace minerals) }\end{array}$ & $\begin{array}{c}\text { Group } \\
\text { II(Antibiotic } \\
\text { only) }\end{array}$ \\
\hline \multirow{3}{*}{$\mathrm{SCC}\left(\times 10^{5} / \mathrm{mL}\right)$} & Day 0 & $9.88 \pm .31^{\mathrm{a}}$ & $10.03 \pm .33^{\mathrm{a}}$ \\
\cline { 2 - 4 } & Day 5 & $6.00 \pm .36^{\mathrm{b}}$ & $7.63 \pm .17^{\mathrm{b}}$ \\
\cline { 2 - 4 } & Day 10 & $3.19 \pm .09^{\mathrm{c}}$ & $4.43 \pm .13^{\mathrm{c}}$ \\
\hline \multirow{3}{*}{ Neutrophil (\%) } & Day 0 & $72.07 \pm 1.09^{\mathrm{a}}$ & $74.75 \pm .99^{\mathrm{a}}$ \\
\cline { 2 - 4 } & Day 5 & $50.20 \pm 1.30^{\mathrm{b}}$ & $50.33 \pm 1.43^{\mathrm{b}}$ \\
\cline { 2 - 4 } & Day 10 & $20.67 \pm .82^{\mathrm{c}}$ & $27.42 \pm .86^{\mathrm{c}}$ \\
\hline \multirow{3}{*}{ Lymphocyte (\%) } & Day 0 & $6.80 \pm .31^{\mathrm{a}}$ & $6.75 \pm .33^{\mathrm{a}}$ \\
\cline { 2 - 4 } & Day 5 & $10.80 \pm .54^{\mathrm{b}}$ & $9.00 \pm .30^{\mathrm{b}}$ \\
\cline { 2 - 4 } & Day 10 & $14.93 \pm .41^{\mathrm{c}}$ & $11.50 \pm .34^{\mathrm{c}}$ \\
\hline \multirow{3}{*}{ Macrophage (\%) } & Day 0 & $21.13 \pm 1.05^{\mathrm{a}}$ & $18.50 \pm 1.05^{\mathrm{a}}$ \\
\cline { 2 - 4 } & Day 5 & $39.00 \pm 1.37^{\mathrm{b}}$ & $40.67 \pm 1.19^{\mathrm{b}}$ \\
\cline { 2 - 4 } & Day 10 & $65.07 \pm 1.10^{\mathrm{c}}$ & $61.08 \pm .87^{\mathrm{c}}$ \\
\hline
\end{tabular}

Values within a column having superscript $(a, b, c)$ with at least one common alphabet do not differ significantly at $5 \%$ level $(\mathrm{p}<0.05)$ from each other.

Table.4 Comparison of trace mineral profile between healthy lactating (control group) and mastitic animals

\begin{tabular}{|c|c|c|}
\hline Parameters & Control Group & Mastitic Group \\
\hline Copper $(\mu \mathrm{mol} / \mathrm{L})$ & $8.25 \pm .07^{\mathrm{a}}$ & $7.01 \pm 0.06^{b}$ \\
\hline Zinc $(\mu \mathrm{mol} / \mathrm{L})$ & $14.47 \pm .31^{\mathrm{a}}$ & $11.71 \pm 0.16^{b}$ \\
\hline Mn $(\mu \mathrm{mol} / \mathrm{L})$ & $3.78 \pm .11^{\mathrm{a}}$ & $2.94 \pm 0.04^{b}$ \\
\hline Se (ng/MI) & $38.47 \pm 1.67^{\mathrm{a}}$ & $31.29 \pm 1.14^{b}$ \\
\hline
\end{tabular}

Values within a row having superscript $(a, b, c)$ with at least one common alphabet do not differ significantly at $5 \%$ level $(\mathrm{p}<0.05)$ from each other.

Table.5 Effect of therapeutic regimens on trace mineral profile of animals with clinical mastitis

\begin{tabular}{|c|c|c|c|}
\hline Parameters & Days of treatment & $\begin{array}{l}\text { Group I (Antibiotic + } \\
\text { Antioxidant trace } \\
\text { minerals) }\end{array}$ & $\begin{array}{l}\text { Group II } \\
\text { (Antibiotic only) }\end{array}$ \\
\hline Copper $(\mu \mathrm{mol} / \mathrm{L})$ & $\begin{array}{l}\text { Day 0 } \\
\text { Day } 10\end{array}$ & $\begin{array}{l}6.88 \pm .06^{\mathrm{a}} \\
7.65 \pm .06^{\mathrm{b}}\end{array}$ & $\begin{array}{l}7.18 \pm .10^{\mathrm{a}} \\
7.12 \pm .13^{\mathrm{a}}\end{array}$ \\
\hline Zinc $(\mu \mathrm{mol} / \mathrm{L})$ & $\begin{array}{l}\text { Day } 0 \\
\text { Day } 10\end{array}$ & $\begin{array}{l}11.86 \pm .222^{a} \\
13.85 \pm .21\end{array}$ & $\begin{array}{l}11.52 \pm .22{ }^{a} \\
11.13 \pm .16^{b}\end{array}$ \\
\hline $\mathrm{Mn}(\mu \mathrm{mol} / \mathrm{L})$ & $\begin{array}{l}\text { Day } 0 \\
\text { Day } 10\end{array}$ & $\begin{array}{l}2.94 \pm .06^{\mathrm{a}} \\
3.30 \pm .03\end{array}$ & $\begin{array}{l}2.94 \pm .04^{\mathrm{a}} \\
2.93 \pm .05^{\mathrm{a}}\end{array}$ \\
\hline Se (ng/mL) & $\begin{array}{l}\text { Day } 0 \\
\text { Day } 10\end{array}$ & $\begin{array}{l}29.94 \pm 1.80^{a} \\
35.39 \pm 1.46^{b}\end{array}$ & $\begin{array}{l}32.98 \pm 1.16^{a} \\
31.67 \pm 1.88^{a}\end{array}$ \\
\hline
\end{tabular}

Values within a row having superscript $(a, b, c)$ with at least one common alphabet do not differ significantly at $5 \%$ level $(p<0.05)$ from each other. 


\section{Macrophage (\%)}

The mean macrophage count (\%)was $68.58 \pm 0.48$ for normal healthy control group and 19.96 \pm 0.77 for the mastitic group (Table 2). The difference in the mean values of macrophage (\%)between the healthy control group the mastitic group was statistically significant $(p<0.05 \%)$. The mean values for macrophage count (\%) for group I animals with clinical mastitis were 21.13 \pm 1.05 , $39 \pm 1.37$ and $65.07 \pm 1.1$ on day 0 , day 5 and day 10 of treatment, respectively. The mean values of macrophage $(\%)$ on day 0,5 and 10 of treatment within group I animals differed significantly from each other $(\mathrm{p}<0.05 \%)$ The mean values for macrophage count $(\%)$ for group II animals were $18.5 \pm 1.05,40.67 \pm 1.19$ and $61.08 \pm 0.87$ on day 0 , day 5 and day 10 of treatment, respectively and the mean values of macrophage (\%) on day 0,5 and 10 within group II animals also differed significantly $(\mathrm{p}<0.05 \%)$ from each other (Table 3$)$.

Differential cell count in milk (DCC) evidences changes in relative cell proportions. These changes can be used to differentiate healthy glands from inflamed or infected ones. It has been proposed as a valid tool for the identification of inflammatory processes (Rivas et al., 2001). Since low SCC can be found in both healthy and infected quarters, milk DCC could be used to identify infected quarters despite low SCC. In fact, studies have shown that DCC can reveal inflammatory processes even in milk with 9000 cells/mL (Schwarz et al., 2011).

\section{Copper (Cu) and Manganese (Mn)}

The mean values of copper and manganese in the mastitic group were statistically significant from the mean values of copper in the normal control group $(\mathrm{p}<0.05 \%)$. The mean values for $\mathrm{Cu}(\mu \mathrm{mol} / \mathrm{L})$ and $\mathrm{Mn}$ $(\mu \mathrm{mol} / \mathrm{L})$ for group I animals in the mastitic group receiving therapeutic regimen I on day 0 and day 10 in group I animals differed significantly from each other $(\mathrm{p}<0.05)$ but the mean values of $\mathrm{Cu}$ and $\mathrm{Mn}$ on day 0 and day 10 in group II did not differ significantly ( $p>0.05)$ from each other (Table 5). Copper is an important co-factor of superoxide dismutase, an enzyme, which protects cells from the pro-oxidative influence of free radicals (Kleczkowski, 2003). In our study the values of copper were low in mastitic animals as compared to healthy control group. Our findings are in agreement with Kleczkowski, 2008 who also found decreased concentrations of copper in animals with clinical mastitis. The present study revealed decreased levels of $\mathrm{Mn}$ in clinical mastitis as compared to normal control group. Our findings of decreased values of $\mathrm{Mn}$ in clinical mastitis are in agreement with Erskine et al., 1997 and Yang and Li, (2015) who also reported that the plasmatic levels of minerals decrease in clinical mastitis.

\section{Zinc (Zn) and Selenium (Se)}

The mean values of $\mathrm{Zn}(\mu \mathrm{mol} / \mathrm{L})$ and $\mathrm{Se}$ $(\mathrm{ng} / \mathrm{mL})$ for normal healthy control group and the mastitic group (Table 4) differed significantly from each other $(\mathrm{p}<0.05)$. The mean values of zinc and selenium on day 0 and day 10 in group I and group II animals differed significantly from each other $(p<0.05)$. In our study, the zinc levels in dairy cows with clinical mastitis were low compared with healthy cows. Ibrahim et al., 2016 also found a significant decrease in the values of zinc in cows with clinical mastitis. Low $\mathrm{Zn}$ status leads to low quality milk with high SCC and increased incidence of mastitis (Gaafar et al., 2010). The present study revealed decreased levels of $\mathrm{Se}$ in clinical mastitis as compared to normal control group. Our findings of low Se values in clinical mastitis are in agreement with Weiss et al., (1990), Erskine et al., (1987), Grasso et al., 
(1990) and Kommisrud et al., (2005). Selenium is an essential micronutrient present in tissues throughout the body and is important physiologically because it is an integral component of the enzyme glutathione peroxidase. Weiss et al., (1990), found that high serum Se concentrations are associated with reduced rates of clinical mastitis and low bulk tank milk SCC.

Mastitis is characterized by change in the milk SCC and DCC as evidenced by the present study. Further supplementation of anti-oxidant trace minerals results in early amelioration of milk SCC and DCC as evidenced by normal values in the group supplemented with anti-oxidants as compared to the group not supplemented with antioxidants. The requirements of trace minerals like $\mathrm{Cu}, \mathrm{Zn}, \mathrm{Mn}$ and $\mathrm{Se}$ are increased in mastitis as evidenced by their decreased levels in clinical mastitis and improved clinical response on their supplementation. Anti-oxidant trace minerals like $\mathrm{Cu}, \mathrm{Zn}, \mathrm{Mn}$ and Se significantly aid recovery in bovine mastitis and may play a significant role in prophylaxis of mastitis in lactating animals.

\section{References}

Alhussein, M., Kaur, M., Manjari, P. , Kimothi, S. P., Mohanty, A.K. and Dang, A. K. 2015.A comparative study on the blood and milk cell counts of healthy, subclinical, and clinical mastitis Karan Fries cows. Veterinary World 8(5): 685-689.

Dang, A.K., Mukherjee, J., Kapila, S., Mohanty, A.K, Kapila, R. and Prasad, S. 2010. In vitro phagocytic activity of milk neutrophils during lactation cycle in Murrah buffaloes of different parity. Journal of Animal Physiology and Animal Nutrition94:706-711.

Erskine, R. J, Bartlett, P. C., Herdt, T. and Gaston, P. 1997.Effects of parenteral administration of vitamin $\mathrm{E}$ on health of periparturient dairy cows. Journal of the American Veterinary Medical Association 211:466-469.

Erskine, R.J., Eberhar, R.J. and Hutchinson, L.J. 1987. Blood selenium concentrations and glutathione peroxidase activities in dairy herds with high and low somatic cell counts. Journal of the American Veterinary Medical Association 11: 1417-1421.

Gaafar, H.M.A., Basiuoni, M.I., Ali, M.F.E., Shitta, A.A. andShamas, A.S.E. 2010. Effect of zinc methionine supplementation on somatic cell count in milk and mastitis in Friesian cows. Archiva Zootechnica13: 36-46.

Grasso, P. J., Scholz, R. W., Erskine,, R. J. and Eberhart, R. J. 1990. Phagocytosis, bactericidal activity, and oxidative metabolism of milk neutrophils from dairy cows fed selenium-supplemented and selenium-deficient diets. American Journal of Veterinary Research 51:269274.

Hamann, J.and Krömker, V.1997. Potential of specific milk composition variables for cow health management. Livestock Production Science48: 201-208.

Ibrahim, H.M.M., El-seedy, Y.Y. and Gomaa, N.A. 2016. Cytokine response and oxidative stress status in dairy cows with acute clinical mastitis. Journal of Dairy, Veterinary \& Animal Research 3(1): 2-6.

Kleczkowski M., Klucinski W., Sitarska E., Sikora J., Kasztelan R. 2003.Influence of mineral nutrition on superoxide dismutase activity in blood of cows. Bulletin of the Veterinary Institute in Pulawy 47 :547-554.

Kleczkowski, M., Kluciński, W.Z., Jakubowski, T., Fabisiak1, M. and Dembele, K. 2008. Copper status and SOD activity in blood of cows affected with clinical mastitis. Bulletin of the 
Veterinary Institute in Pulawy 52:387390.

Kommisrud, E., Østerås, O. and Vatn, T. 2005. Blood Selenium Associated with Health and Fertility in Norwegian Dairy Herds. Acta Veterinaria Scandinavica 46:229-240.

Leitner, G., Shoshani, E., Krifucks, O., Chaffer, M. and Saran, A. 2000. Milk leukocyte population patterns in bovine udder infection of different aetiology. Journal of Veterinary Medicine. B, Infectious Diseases and Veterinary Public Health 47: 581-589.

Östensson, K., Hageltorn, M.and Astrom, G. 1988. Differential cell counting in fraction-collected milk from dairy cows. Acta Veterinaria Scandinavica 29 : 493500.

Rivas, A.L., Quimby, F.W., Blue, J. and Coksaygan, O. 2001. Longitudinal evaluation of bovine mammary gland health status by somatic cell counting, flow cytometry and cytology. Journal of Veterinary Diagnosis and Investigations 13:399-407.

Sandholm, M.1995. Detection of inflammatory changes in the milk. In: The bovine udder and mastitis (Gummerus Sandholm M., HonkanenBuzalski T., Kaartinen L., Pyörälä
S.Eds.), Jyväskylä, Finland, pp.89-104. Schwarz, D., Diesterbeck, U.S., Koenig, S., Bruegemann, K., Schlez, K., Zschoeck, M., Wolter, W. and Czerny, C. P. 2011. Microscopic differential cell counts in milk for the evaluation of inflammatory reactions in clinically healthy and subclinically infected bovine mammary glands. Journal of Dairy Research78:448-455.

Sharma, A., Dhingra, P., Pander, B.L. and Kumar, R. 2006. Bovine subclinical mastitis: prevalence and treatment with homeopathic medicine. International Journal of Cow Science 2:1.

Sharma, N., Singh, N.K. and Bhadwal, M.S. 2011. Relationship of Somatic Cell Count and Mastitis: An Overview. Asian-Australasian Journal of Animal Sciences 24(3): 429.

Weiss, W.P., Hogan, J.S.and Smith, K.L.1990. Relationships among selenium, vitamin Eand mammary gland health in commercial dairy herds. Journal of Dairy Science 73:381.

Yang, F. L.and Li, X. S. 2015.Role of antioxidant vitamins and trace elements in mastitis in dairy cows. Journal of Advanced Veterinary Animal Research 2 (1): 1-9.

\section{How to cite this article:}

Muhee A., H. U. Malik, I. Asharaf, O. S. Shah, A. Jan, Muheet, W. Rather and Showkeen Muzamil. 2017. Effect of Supplementation of Anti-Oxidant Mineral Formulation on Milk SCC and DCC in Bovine Mastitis. Int.J.Curr.Microbiol.App.Sci. 6(7): 4600-4608.

doi: https://doi.org/10.20546/ijcmas.2017.607.482 